\title{
OPTIMIZATION OF ULTRASONIC-ASSISTED EXTRACTION PARAMETERS FOR ANTIOXIDANTS FROM Curcuma longa L.
}

\author{
Saliha ŞAHINN \\ Bursa Uludağ University, Faculty of Science and Arts, Department of Chemistry, 16059, Bursa, TURKEY \\ ORCID ID: orcid.org/0000-0003-2887-5688, e-mail: salihabilgi@uludag.edu.tr
}

Cite this article as:

Şahin S. 2018. Optimization of Ultrasonic-Assisted Extraction Parameters for Antioxidants from Curcuma longa L. Trakya Univ J Nat Sci, 19(2): 121128, DOI: $10.23902 /$ trkjnat.344985

Received: 18 October 2017, 06 August 2018, Online First: 08 August 2018, Published: 15 October 2018

\begin{abstract}
In this study, ultrasonication was used to extract antioxidant compounds such as polyphenols, flavonoids, and curcuminoids from turmeric (Curcuma longa L.) The influences of time, ethanol concentration and temperature as three independent factors on the extraction of the total phenolic content were evaluated by the Folin-Ciocalteu method and the antioxidant capacities by the ABTS and chromium reducing antioxidant capacity (CHROMAC) methods. The central composite design (CCD) with a multi-response surface methodology (MRSM) was used for the statistical modeling of the response data followed by the regression and analysis of variance (ANOVA) to determine the significance of the model and the factors. The response predictions obtained at optimum extraction conditions of an extraction time of 64min, an ethanol concentration of $82 \%(\mathrm{v} / \mathrm{v})$ and an extraction temperature of $32^{\circ} \mathrm{C}$ were $47.32 \mathrm{mg} \mathrm{GAE} / \mathrm{g}$ (for Folin-Ciocalteu), 29.15 (for ABTS) and $5.17 \mathrm{mg}$ TE/g (for CHROMAC). The predicted values obtained from the multi-response surface methodology agreed with the experimental values data 95\% confidence level. These data indicate that the multi-response surface methodology is applicable for optimizing the ultrasonic-assisted extraction of antioxidant compounds from C. longa.
\end{abstract}

Keywords: Curcuma longa L., ultrasonic-assisted extraction, antioxidant capacity, phenolic compounds, multi-response surface methodology.

Özet: Bu çalışmada ultrasonikasyon, Curcuma longa L.'da bulunan polifenol, flavonoid ve kurkuminoid gibi antioksidan bileşiklerin ekstraksiyonu için kullanılmıştır. Zaman, etanol derişimi ve sıcaklık gibi 3 bağımsız değişkenin toplam fenolik madde (Folin yöntemi) ve antioksidan kapasite (ABTS ve CHROMAC yöntemi) üzerine etkisi değerlendirilmiştir. Merkezi kompozit dizayn ile çok yanıtlı yüzey analiz yöntemi, sonuçların istatistiksel modellenmesi, model ve faktörler arası etkileşimi belirlemek için regresyon ve ANOVA analizinde kullanılmıştır. Belirlenen optimum koşullarda (64dk ekstraksiyon zamanı, $\% 82$ (v/v) etanol derişimi ve $32^{\circ} \mathrm{C}$ ekstraksiyon sıcaklığı) toplam fenolik madde miktarı 47,32mg GAE/g, antioksidan kapasite 29,15 (ABTS) ve 5,17 (for CHROMAC) $\mathrm{mg}$ TE/g bulunmuştur. Bu deneysel değerler ile tahmini değerler \%95 güven aralığında birbiri ile uyumludur. Buna göre çok yanıtlı yüzey analiz tekniği (MRSM), C. longa'dan antioksidan bileşiklerin ultrasonikdestekli ekstraksiyon optimizasyonu için güvenle kullanılabilir.

\section{Introduction}

Curcuma longa L. (turmeric) distributed in East and South-East Asia (Xu et al. 2017)is generally used as a functional food and an herbal medicine (Péret-Almeida et al. 2005). The curcuminoids (curcumin-Cur, demethoxycurcumin-DMC, bisdemethoxycurcuminBDMC) are natural and active phytochemicals in turmeric (Xu et al. 2017). A large number of studies reported that curcuminoids possess strong antioxidant (MartínezMorúa et al. 2013), anti-inflammatory (Kant et al. 2014), antimicrobial (Kiamahalleh et al. 2016), and anticarcinogenic (Riela et al. 2014) properties and some other pharmaceutical activities (Lima et al. 2011, Mourtas et al. 2014).

Curcuminoids can be extracted from plants using a variety of methods. Non-conventional extraction techniques include ultrasound-assisted (Mandal et al.
2009), supercritical fluid, pressurized liquid and microwave extractions (Mandal et al. 2008). Among these techniques, ultrasound-assisted extraction (UAE) is widely used for the extraction of phytochemicals and is a simple, inexpensive, energy-saving, and efficient method when compared with other extraction techniques (Nasir et al. 2017). UAE was used for the extraction of antioxidant compounds from plants with higher yields (Şahin et al. 2013).

Different methods have been suggested for the extraction of phytochemicals from plants and the optimization of the extraction conditions due to the differences in the chemical and physical properties, concentrations, and matrix complexity related to the extractable phytochemical. The extraction solvent, $\mathrm{pH}$, temperature, time, solid/liquid ratio, pressure, and particle 
size are typical factors that contribute to the yield of extraction. Optimizing one factor at a time has been a generally used approach (Lai et al. 2014), but it is timeconsuming and expensive and does not allow the analysis of possible interactions among the extraction variables (Matshediso et al. 2015). Therefore, a multi-response surface methodology (MRSM) is considered an efficient method for evaluating multiple individual parameters and their interactions (Baş \& Boyac1 2007). The extraction of antioxidant compounds has been recently studied using different solvents such as dichloromethane, hexane, methanol, ethanol, acetone, dimethyl ether, diethyl ether, dimethyl sulfoxide, toluene, 2-propanol, and n-butanol. Due to the high solvent costs, the toxicity resulting from the solubility of the bioactive compounds in the solvent and low extraction efficiency, these solvents have been used regularly for the extraction of antioxidant compounds. Therefore, ethanol is one of the appropriate extraction solvents for antioxidant compounds due to its low cost, "green" characteristics, ease of access and safety for direct use in foods and pharmaceuticals ( $\mathrm{Xu} \& \mathrm{Bao}$ 2014, Dailey \& Vuong 2015).

The present study is focused on the application of UAE using a multi-response surface methodology to optimize the antioxidant extraction parameters for $C$. longa. Three extraction factors -the ethanol concentration, extraction temperature, and extraction time- were optimized by the MRSM. A three-variable and five-level, central composite design was used for simultaneously maximizing the antioxidant capacity and the total phenolic content.

\section{Materials and Methods}

\section{Chemicals and reagents}

Trolox, Folin-Ciocalteu reagent and ABTS were purchased from Sigma. Ethanol and methanol (HPLC grade), formic acid, phosphoric acid, sodium dihydrogen phosphate and $\mathrm{HCl}$ were purchased from Merck. Potassium dichromate, 1,5-diphenylcarbazide, sodium carbonate, potassium sodium tartrate, sodium hydroxide, copper(II) sulfate pentahydrate, and gallic acid in HPLC grade were obtained from Sigma.

\section{Plant material}

Dried Curcuma longa L. was purchased from a medicinal market in Bursa-Turkey and was stored at $4^{\circ} \mathrm{C}$ until extraction.

\section{Ultrasound-Assisted Extraction (UAE) method}

An ultrasonic cleaner (United model, Bursa, Turkey) was used for the extraction. The temperature was controlled using a resistance thermometer. Curcuma longa $(0.5 \mathrm{~g})$ was placed in a vial, ethanol $(30 \mathrm{~mL})$ was added, and the solution was placed in an ultrasonic cleaning bath. The operation was performed at $40 \mathrm{~Hz}$ ultrasonic wave frequency. The extraction parameters are given in Table 1.
Table 1. Range of coded and actual values for central composite design.

\begin{tabular}{lccccc}
\hline \multicolumn{1}{c}{ Factor } & \multicolumn{5}{c}{ Level } \\
& $\mathbf{- 2}$ & $\mathbf{- 1}$ & $\mathbf{0}$ & $\mathbf{1}$ & $\mathbf{2}$ \\
\hline \hline Extraction time (min) & 19 & 30 & 45 & 60 & 71 \\
Ethanol concentration $(\boldsymbol{\%}, \mathbf{v} / \mathbf{v})$ & 23 & 30 & 40 & 50 & 57 \\
Extraction temperature $\left({ }^{\circ} \mathbf{C}\right)$ & 15 & 30 & 50 & 70 & 85 \\
\hline \hline
\end{tabular}

\section{Antioxidant capacity}

The antioxidant capacities of the extracts were determined with the chromium reducing antioxidant capacity (CHROMAC) (Işık et al. 2013) and ABTS (Re et al. 1999) methods with slight modifications (Şahin et al. 2013, Nasir et al. 2017). In the ABTS method, $3.8 \mathrm{ml}$ of ethanol was added to the $C$. longa sample $(0.2 \mathrm{ml})$. Then, $1 \mathrm{ml}$ of the ABTS solution (diluted with ethanol at a ratio of $1: 10$ ) was added. The absorbance of the sample was measured at $734 \mathrm{~nm}$ against a blank sample after $6 \mathrm{~min}$ by Varian Cary-50 UV/VIS spectrophotometer (Melbourne, Australia). The resulting antioxidant capacity was expressed as mg of Trolox equivalents (TE) per gram of sample. In the CHROMAC method, approximately $0.2 \mathrm{ml} \mathrm{C}$. longa sample, $0.3 \mathrm{ml}$ distilled water, $3.5 \mathrm{ml}$ phosphate buffer solution ( $\mathrm{pH} 2.8$ ) and $0.5 \mathrm{ml}$ $\mathrm{K}_{2} \mathrm{Cr}_{2} \mathrm{O}_{7}$ (50mg l-1) were added into a test tube. The $\mathrm{K}_{2} \mathrm{Cr}_{2} \mathrm{O}_{7}$ solution was allowed to react with the sample. After incubation for $1 \mathrm{~min}$, approximately $0.5 \mathrm{ml}$ of 1,5 diphenylcarbazide $\left(3.4 \times 10^{-4} \mathrm{~mol} \mathrm{~L}^{-1}\right)$ was added and mixed thoroughly. The absorbance of the solution was measured at 540nm against a reagent blank after $50 \mathrm{~min}$. The reagent blank at $\mathrm{pH} 1.2$ was prepared with $0.1 \mathrm{M}$ citric acid and $6 \mathrm{M} \mathrm{HCl}$. A standard calibration curve was prepared using various concentrations of Trolox. The results were expressed as $\mathrm{mg}$ TE per gram of sample.

\section{Total phenolic content}

Total phenolic content was determined using the Folin-Ciocalteu method (Singleton et al. 1999) with slight modifications (Şahin et al. 2013). 50mL of Lowry A solution ( $2 \%$ aqueous $\mathrm{Na}_{2} \mathrm{CO}_{3}$ in $0.1 \mathrm{M} \mathrm{NaOH}$ ) was mixed with $1 \mathrm{~mL}$ of Lowry B solution $\left(0.5 \% \mathrm{CuSO}_{4}\right.$ solution in $1 \% \mathrm{NaKC}_{4} \mathrm{H}_{4} \mathrm{O}_{6}$ aqueous solution) to produce Lowry $\mathrm{C}$ solution. Briefly, $1.8 \mathrm{ml}$ of distilled water and $2.5 \mathrm{ml}$ of Lowry C solution were added to $C$. longa sample $(0.2 \mathrm{ml})$, and the mixture was left for $10 \mathrm{~min}$. After $10 \mathrm{~min}$, Folin reagent $(0.25 \mathrm{ml})$ was added and the blue color of the mixture was allowed to stabilize under darkness for approximately $30 \mathrm{~min}$. The absorbance of the sample was measured at $750 \mathrm{~nm}$ in triplicate. The total phenolic contents of $C$. longa extracts were expressed as $\mathrm{mg}$ gallic acid equivalent (GAE) per g of $C$. longa.

\section{Response surface methodology}

A central composite design (CCD) was selected for the optimal extraction conditions for the most successful RSM design (Aybastier \& Demir 2010). A three-factor, four-level central composite design experimental design matrix with factors such as the extraction time ( $\mathrm{min}$ ), ethanol concentration $(\%, v / v)$ and extraction temperature $\left({ }^{\circ} \mathrm{C}\right)$ (Table 1) was formed, and the responses were 
selected as the maximum antioxidant capacity and the total phenolic content. Twenty experiments were performed to optimize the parameters (Aybast1er \& Demir 2010). Design Expert 7.0.0 software (Stat-Ease Inc., USA) was used for the statistical analysis.

\section{Results}

\section{MRSM model}

The MRSM was used to determine the extraction conditions that give the best results in terms of the antioxidant capacity and total phenolic content. The experimental and predicted total phenolic content and antioxidant capacity values are shown in Table 2 . The extraction time, ethanol concentration and extraction temperature were studied with respect to the UAE of $C$. longa. The results indicate good correlations between the parameters because of a satisfactory $R$-squared value $\left(R^{2}\right.$ $=0.902$ ) (Table 3 ). The $F$-value and $p$-values are indicated by larger corresponding coefficients. The $x_{1}$ (extraction time), $x_{2}$ (ethanol volume), $x_{3}$ (extraction temperature), $x_{1} x_{3}, x_{2} x_{3}$ and $x_{2}^{2}$ variables were the most significant factors $(p \leq 0.05)$ (Table 4). However, $x_{1} x_{2}, x_{1}^{2}$ and $x_{2}^{2}$ had less effect (where $p>0.05$ ) on the UAE in terms of the total phenolic content. The effects of the extraction factors on the total phenolic content were studied using response surface plots (Fig. 1). The MRSM of the data in Table 3 also showed good correlation $\left(R^{2}=0.895\right.$ for ABTS and 0.826 for CHROMAC). The $x_{1}, x_{2}, x_{3}, x_{1} x_{3}, x_{2} x_{3}, x_{1}{ }^{2}, x_{2}{ }^{2}$ and $x_{3}^{2}$ variables for ABTS and the $x_{1}, x_{2}, x_{3}, x_{2} x_{3}, x_{1}^{2}$ and $x_{3}{ }^{2}$ variables for CHROMAC were the most significant factors $(p \leq 0.05)$ (Table 4$)$ for the UAE of antioxidant compounds from $C$. longa. The $x_{1} x_{2}$ variable for ABTS and $x_{1} x_{2}, x_{1} x_{3}, x_{2}^{2}$ for CHROMAC had minor effects on the antioxidant capacity derived from the UAE. The effects of the factors and antioxidant capacity values determined with the ABTS and CHROMAC methods were analyzed using response surface plots from the MRSM in Fig. 2.

\section{Optimization of the extraction parameters}

Validation tests were used to verify the reliability of the model by comparing the experimental and the predicted values for the MRSM. The optimum UAE conditions were presented in Table 5. An extraction time of $64 \mathrm{~min}$, an ethanol concentration of $82 \%(\mathrm{v} / \mathrm{v})$, and an extraction temperature of $32^{\circ} \mathrm{C}$ produced the maximum antioxidant capacities $(29.15 \mathrm{mg} \mathrm{TE} / \mathrm{g}$ for $\mathrm{ABTS}$ and $5.17 \mathrm{mg}$ TE/g for CHROMAC) and the total phenolic content (47.32mg GAE/g) from C. longa. After comparing the predicted and experimental results, the RSM was more stable with good correlation $\left(R^{2}>0.95\right)$ for $C$. longa.

Table 2. Central composite design of factors with experimental and predicted values.

\begin{tabular}{|c|c|c|c|c|c|c|}
\hline \multirow{2}{*}{\multicolumn{3}{|c|}{ Total phenolic content (mg GAE/g dried plant) }} & \multicolumn{4}{|c|}{ Antioxidant capacity (mg TE/g dried plant) } \\
\hline & & & \multicolumn{2}{|c|}{ ABTS } & \multicolumn{2}{|c|}{ CHROMAC } \\
\hline Treatment & Experimental & Predicted & Experimental & Predicted & Experimental & Predicted \\
\hline 1 & 42.32 & 43.68 & 7.63 & 5.33 & 2.16 & 1.33 \\
\hline 2 & 18.34 & 17.95 & 5.56 & 5.21 & 0.16 & 0.17 \\
\hline 3 & 44.21 & 47.70 & 19.92 & 22.36 & 3.51 & 4.36 \\
\hline 4 & 42.93 & 42.36 & 11.05 & 10.81 & 2.55 & 2.47 \\
\hline 5 & 46.55 & 48.12 & 9.49 & 9.84 & 3.62 & 3.74 \\
\hline 6 & 42.74 & 42.79 & 5.43 & 7.49 & 2.62 & 3.26 \\
\hline 7 & 41.49 & 43.68 & 4.81 & 5.33 & 1.09 & 1.33 \\
\hline 8 & 38.54 & 43.68 & 6.33 & 5.33 & 0.67 & 1.33 \\
\hline 9 & 46.35 & 43.68 & 2.86 & 5.33 & 1.51 & 1.33 \\
\hline 10 & 46.77 & 46.01 & 12.91 & 10.58 & 4.09 & 3.34 \\
\hline 11 & 32.46 & 32.23 & 14.57 & 15.04 & 2.93 & 2.90 \\
\hline 12 & 47.37 & 43.68 & 6.63 & 5.33 & 1.25 & 1.33 \\
\hline 13 & 36.57 & 38.62 & 5.46 & 8.58 & 0.94 & 1.78 \\
\hline 14 & 46.45 & 41.98 & 13.67 & 10.64 & 3.97 & 3.06 \\
\hline 15 & 46.00 & 43.68 & 3.70 & 5.33 & 1.31 & 1.33 \\
\hline 16 & 45.34 & 46.86 & 13.05 & 13.19 & 1.62 & 1.72 \\
\hline 17 & 20.78 & 24.47 & 6.65 & 7.53 & 0.18 & 0.39 \\
\hline 18 & 45.80 & 43.37 & 20.76 & 20.66 & 2.10 & 1.96 \\
\hline 19 & 33.46 & 30.98 & 10.64 & 9.91 & 1.38 & 1.22 \\
\hline 20 & 41.00 & 39.98 & 19.56 & 16.90 & 3.45 & 2.76 \\
\hline
\end{tabular}


Table 3. Analysis of variance (ANOVA) for the fitted quadratic polynomial model for optimization of extraction parameters.

\begin{tabular}{|c|c|c|c|c|c|c|c|c|c|c|c|c|c|c|c|}
\hline \multirow[b]{2}{*}{ Source } & \multicolumn{5}{|c|}{ Folin $\left(R^{2}=0.902\right)$} & \multicolumn{5}{|c|}{$\operatorname{ABTS}\left(R^{2}=0.895\right)$} & \multicolumn{5}{|c|}{ CHROMAC $\left(\mathbf{R}^{2}=0.826\right)$} \\
\hline & DF & SS & MS & $\begin{array}{c}F \\
\text { value }\end{array}$ & $\begin{array}{c}p \\
\text { value }\end{array}$ & DF & SS & MS & $\begin{array}{c}F \\
\text { value }\end{array}$ & $\begin{array}{c}p \\
\text { value }\end{array}$ & DF & SS & MS & $\begin{array}{c}F \\
\text { value }\end{array}$ & $\begin{array}{c}p \\
\text { value }\end{array}$ \\
\hline Model & 9 & 1188.05 & 132.01 & 10.30 & 0.0006 & 9 & 519.61 & 57.73 & 9.55 & 0.0008 & 9 & 23.99 & 2.67 & 5.28 & 0.0079 \\
\hline $\begin{array}{l}\text { Lack } \\
\text { of fit }\end{array}$ & 5 & 68.98 & 13.80 & 1.17 & 0.4354 & 5 & 43.45 & 8.69 & 2.55 & 0.1633 & 5 & 3.82 & 0.76 & 3.13 & 0.1178 \\
\hline $\begin{array}{l}\text { Pure } \\
\text { error }\end{array}$ & 5 & 59.19 & 11.84 & & & 5 & 17.01 & 3.40 & & & 5 & 1.22 & 0.24 & & \\
\hline
\end{tabular}

Table 4. Second order polynomial equations and regression coefficients of the response variables (the extraction time; $\mathrm{x}_{1}$; the ethanol concentration; $\mathrm{x}_{2}$, the extraction temperature; $\left.\mathrm{x}_{3}\right)$.

\begin{tabular}{|c|c|}
\hline Responses & Second order polynomial equations \\
\hline $\begin{array}{l}\text { Total phenol content } \\
\text { (mg GAE/g dried plant) }\end{array}$ & $\mathrm{y}=43,68+2,13 x_{1}+5,40 x_{2}+4,67 x_{3}-3,05 x_{1} x_{3}-4,29 x_{2} x_{3}-3,19 x_{2}^{2}$ \\
\hline $\begin{array}{c}\text { ABTS } \\
\text { (mg TE/g dried plant) }\end{array}$ & $\mathrm{y}=5,33+0,58 x_{1}+3,75 x_{2}-1,53 x_{3}-1,96 x_{1} x_{3}-2,29 x_{2} x_{3}+1,42 x_{1}^{2}+2,86 x_{2}^{2}+2,46 x_{3}^{2}$ \\
\hline $\begin{array}{c}\text { CHROMAC } \\
\text { (mg TE/g dried plant) }\end{array}$ & $\mathrm{y}=1,33+0,45 x_{1}+0,45 x_{2}+0,25 x_{3}-0,98 x_{2} x_{3}+0,41 x_{1}^{2}+0,69 x_{3}^{2}$ \\
\hline
\end{tabular}

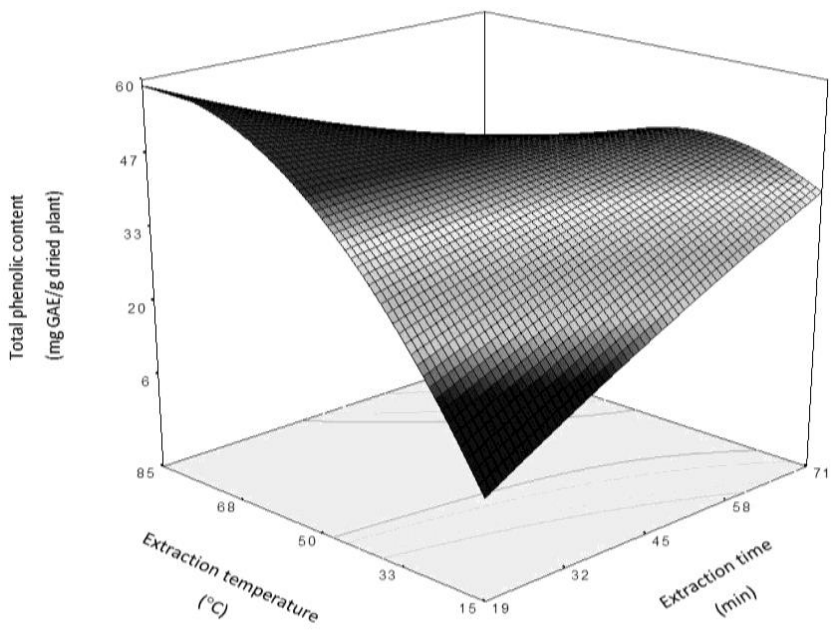

(A)

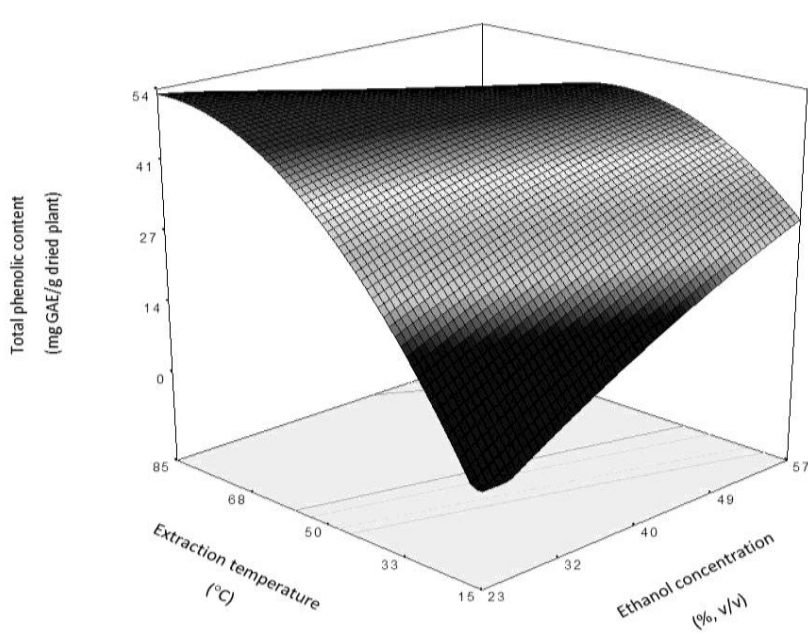

(B)

Fig. 1. Response surface plots of Curcuma longa showing the effects of (A) Extraction time and extraction temperature, (B) Ethanol concentration and extraction temperature on total phenolic content.

\section{Discussion}

Among the 15 runs (Table 3), experiment 12 (45min, $23 \%(\mathrm{v} / \mathrm{v})$ of ethanol, $\left.50^{\circ} \mathrm{C}\right)$ produced the highest total phenolic content $(47.37 \mathrm{mg} \mathrm{GAE} / \mathrm{g}$ ), and experiment 10 $\left(19 \mathrm{~min}, 40 \%(\mathrm{v} / \mathrm{v})\right.$ of ethanol, $\left.50^{\circ} \mathrm{C}\right)$ produced the highest antioxidant capacity $(4.09 \mathrm{mg} \mathrm{TE} / \mathrm{g})$ for the CHROMAC method. For both the Folin-Ciocalteu and CHROMAC methods, experiment 2 produced the lowest values (18.34mg GAE/g and $0.16 \mathrm{mg} \mathrm{TE} / \mathrm{g}$ ). For the ABTS method, experiment 18 produced the highest antioxidant capacity $(20.76 \mathrm{mg} \mathrm{TE} / \mathrm{g})$, but experiment 9 produced the lowest antioxidant capacity $(2.86 \mathrm{mg} \mathrm{TE} / \mathrm{g})$.

ANOVA revealed that the total phenolic content and antioxidant capacity values were described by quadratic polynomial models. The analysis showed that the large model $F$-values (10.30, 9.55 and 5.23 for Folin-Ciocalteu, ABTS and CHROMAC methods, respectively) and the lack of fit $p$-values $(0.4354,0.1633$ and 0.1178 for FolinCiocalteu, ABTS and CHROMAC methods, respectively) were statistically significant at a $95 \%$ confidence level (Table 4). The larger $p$-values were statistically nonsignificant relative to the pure errors. The $\mathrm{R}^{2}$ values were $0.902,0.895$ and 0.826 for the Folin-Ciocalteu, ABTS and CHROMAC methods, respectively. It was shown that the linear relationship between the extraction parameters and the responses were significant and the model was appropriate for optimization.

The three-dimensional images of the response surface methodology showed the interactions between the extraction parameters and the total phenolic content (Fig. 1). At higher extraction temperatures and time, the 
highest total phenolic content was observed (Fig. 1a). The diffusion and solubility rates of the antioxidant compounds increased with a higher extraction temperature. When experiments 13 and 17 were compared (Table 3 ), the total phenolic content increased from 20.78 to $36.57 \mathrm{mg}$ GAE/g dried plant at a higher extraction temperature. Consequently, the effect of increasing the extraction temperature was significant for extracting antioxidant compounds in $C$. longa. Unfortunately, the extraction temperature was an important factor affecting the activity of the extracts due to both the degradation or loss of the antioxidant compounds (Yap et al. 2009, Dorta et al. 2012) and reactions with other components. However, the highest total phenolic content and antioxidant capacity values were obtained at $32^{\circ} \mathrm{C}$ by using the MRSM.

Ethanol was selected as the solvent for the UAE of antioxidant compounds from C. longa. A higher total phenolic content was observed at higher ethanol concentrations (Fig. 1b.). When experiments 6 and 8 are compared (Table 3), it appeared that the total phenolic content increased from 38.54 to $42.93 \mathrm{mg}$ GAE/g dried plant with increasing ethanol concentrations. It was reported that the higher ethanol concentration gave the highest extraction yield of the antioxidant compounds (Kwang et al. 2010). Therefore, the extraction yield of the antioxidant compounds was higher when the total phenolic content and antioxidant capacity of the extract was higher, as shown in our results.

It was clear that when the temperature was increased with a shorter extraction time, the antioxidant capacity was also increased for the ABTS method. The highest antioxidant capacity was observed at the shortest extraction time $(19 \mathrm{~min})$ and the highest temperature $\left(85^{\circ} \mathrm{C}\right)$. Fig. $2 \mathrm{a}-\mathrm{b}$ shows the interactions between the ethanol concentration and extraction temperature on the antioxidant capacity for the ABTS and CHROMAC methods. The antioxidant capacity increased with increasing temperature at a low ethanol concentration. At lower ethanol concentrations and higher temperatures, the highest antioxidant capacity was observed. It was reported that the extraction yield of antioxidant compounds increased with increasing extraction time (Xu et al. 2015). Thus, an extraction time ranging from 19 to $71 \mathrm{~min}$ was used in the present study, and the extraction yield of antioxidant compounds was affected by the extraction temperature. A high temperature may improve the solubility of antioxidant compounds (Liang et al. 2017), but there is an important risk of thermal degradation of antioxidant compounds. The solvent concentration is an important factor influencing extraction yield of antioxidant compounds and extraction yield of antioxidant compounds increased with increasing solvent concentration (volume) (Xu et al. 2015).With the antioxidant capacity as the reference value from Fig. 2, the optimum conditions obtained by the MRSM analysis were an extraction temperature of $85^{\circ} \mathrm{C}$, an extraction time of $19 \mathrm{~min}$ and an ethanol concentration of $23 \%(\mathrm{v} / \mathrm{v})$. However, with the antioxidant capacity and the total phenolic content values as the reference value, the optimum conditions obtained by the MRSM analysis were an extraction temperature of $32^{\circ} \mathrm{C}$, an extraction time of $64 \mathrm{~min}$ and an ethanol concentration of $82 \%(\mathrm{v} / \mathrm{v})$. The optimum conditions were obtained from the MRSM analysis to predict the maximum values for the antioxidant capacities and the total phenolic content. Multi-response surface methodology is the most suitable method for optimizing the ultrasonic-assisted extraction of antioxidant compounds from $C$. long $a$ when compared a single response surface methodology. Because, multiresponse surface methodology ensured the optimum extraction parameters with limit of time and solvent concentration and without no thermal degradation. Furthermore, the antioxidant capacity is dependent on the synergistic effect of the extracted antioxidant compounds. However, the synergistic effect will decrease when the total phenolic content increase (Thoo et al. 2010). Additionally, when compared with the available published data, similar results were found showing that the antioxidant capacity increased with increasing extraction time (Xu et al. 2015).

UAE was also used successfully for the extraction of antioxidant compounds from $C$. longa with yields higher than previously reported (Xu et al. 2015, 2017). The multi-response surface methodology was successful in optimizing the antioxidant compound content using UAE from C. longa.

Table 5. Optimum conditions, predicted and experimental values of responses.

\begin{tabular}{|c|c|c|c|c|c|}
\hline \multirow[b]{2}{*}{ Responses } & \multicolumn{3}{|c|}{ Optimum Ultrasonic-assisted extraction conditions } & \multicolumn{2}{|c|}{ Maximum values } \\
\hline & $\begin{array}{l}\text { Extraction time } \\
(\text { min })\end{array}$ & $\begin{array}{c}\text { Ethanol concentration } \\
(\%, v / v)\end{array}$ & $\begin{array}{c}\text { Extraction } \\
\text { temperature } \\
\left({ }^{\circ} \mathrm{C}\right) \\
\end{array}$ & Predicted & Experimental \\
\hline $\begin{array}{l}\text { Total phenolic content } \\
\text { (mg GAE/g dried plant) }\end{array}$ & 64 & 82 & 32 & 477.63 & $47.32 \pm 0.02$ \\
\hline $\begin{array}{c}\text { ABTS } \\
\text { (mg TE/g dried plant) }\end{array}$ & & & & 29.50 & $29.15 \pm 1.05$ \\
\hline $\begin{array}{c}\text { CHROMAC } \\
\text { (mg TE/g dried plant) }\end{array}$ & & & & 5.13 & $5.17 \pm 0.08$ \\
\hline
\end{tabular}




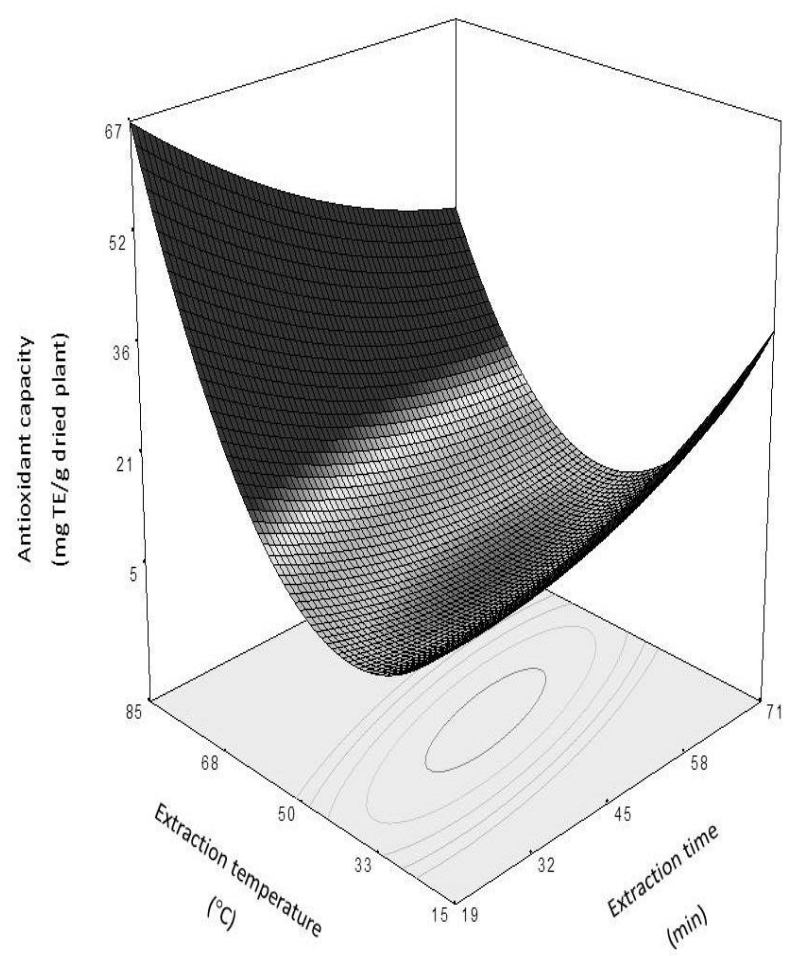

(A)

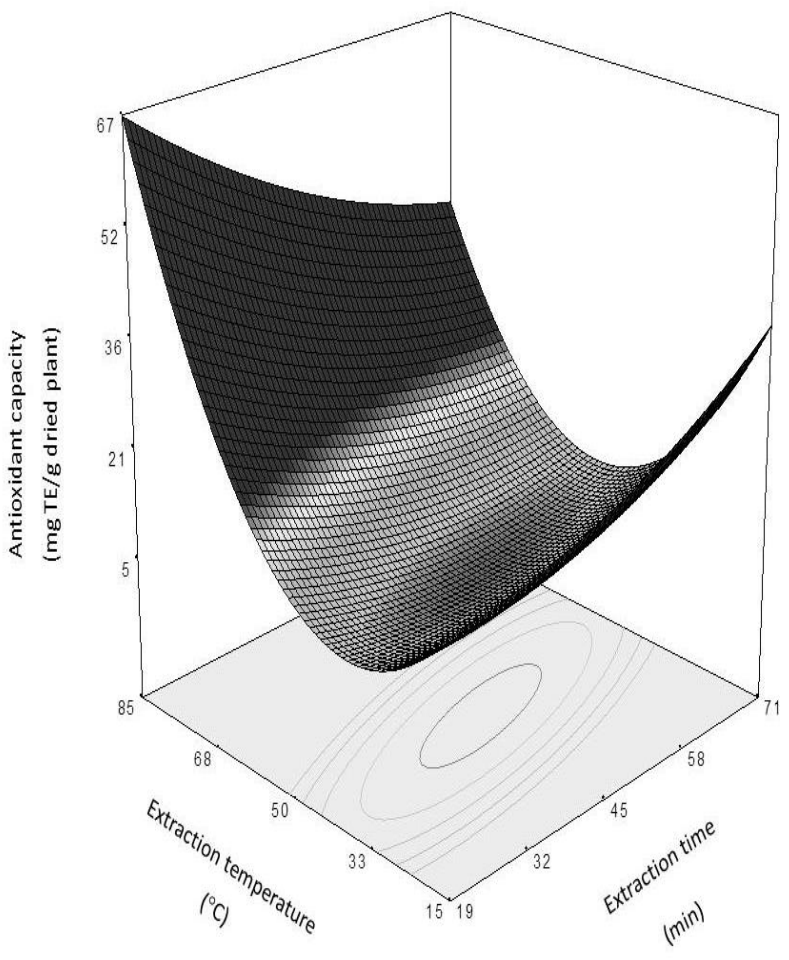

(B)

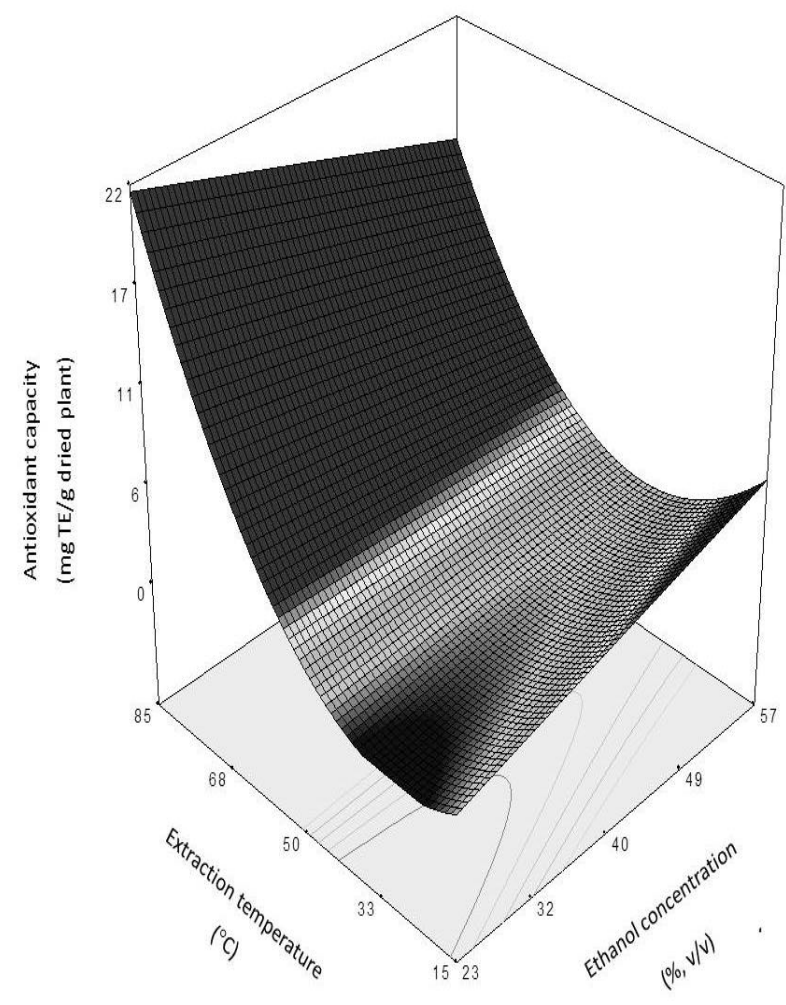

(C)

Fig. 2. Response surface plots of Curcuma longa showing the effects of (A) Extraction time and extraction temperature, (B) Ethanol concentration and extraction temperature on ABTS values, and (C) Ethanol concentration and extraction temperature on CHROMAC value. 
The optimum conditions using UAE of antioxidants from $C$. longa are shown in Table 5.The study of Xu et al. (2017) with $C$. longa have demonstrated that phenolics such as curcuminoids are major contributors to antioxidant properties. Therefore, the total phenolic content and antioxidant capacity have been selected as the response of the MRSM model. All responses from each extraction factor were combined into a single set of optimum conditions. When the multi-response surface methodology was used, the total phenolic content of the extract increased with antioxidant capacity (Nasir et al. 2017). The present study is the first study about determination of the antioxidant capacity of $C$. longa by

\section{References}

1. Aybast1er, Ö. \& Demir, C. 2010. Optimization of immobilization conditions of Thermomyces lanuginosus lipase on styrene-divinylbenzene copolymer using response surface methodology. Journal of Molecular Catalysis B: Enzymatic, 63: 170-178.

2. Baş, D. \& Boyaci, I.H. 2007. Modeling and optimization I: Usability of response surface methodology. Journal of Food Engineering, 78: 836-845.

3. Dailey, A. \& Vuong, Q.V. 2015. Optimization of aqueous extraction conditions for recovery of phenolic content and antioxidant properties from macadamia (Macadamia tetraphylla) skin waste. Antioxidants, 4: 699-718.

4. Dorta, E., Lobo, M.G. \& González, M. 2012. Using drying treatments to stabilise mango peeland seed: effect on antioxidant activity. LWT-Food Science and Technology, 45: 261-268.

5. Işık, E., Şahin, S. \& Demir, C. 2013. Development of a new chromium reducing antioxidant capacity (CHROMAC) assay for plants and fruits. Talanta, 111: 119-124.

6. Kant, V., Gopal, A., Pathak, N.N., Kumar, P., Tandan, S.K. \& Kumar, D. 2014. Antioxidant and anti-inflammatory potential of curcum in accelerated the cutaneous woundhealing in streptozotocin-induced diabeticrats. International Immunopharmacology, 20: 322-330.

7. Kiamahalleh, M.V., Najafpour-Darzi, G., Rahimnejad, M., Moghadamnia, A.A. \& Kiamahalleh, M.V. 2016. High performance curcum in subcritical water extraction from turmeric (Curcuma longa L.). Journal of Chromatography B, 1022: 191-198.

8. Kwang, H.C., Lee, H.J., Koo, S.Y., Song, D.G., Lee D.U. \& Pan C.H. 2010. Optimization of pressurized liquid extraction of carotenoids and chlorophylls from Chlorella vulgaris. Journal of Agricultural and Food Chemistry, 58: 793-797.

9. Lai, J., Wang, H., Wang, D., Fang, F., Wang F. \& Wu T. 2014. Ultrasonic extraction of antioxidants from Chinese sumac (Rhus typhina L.) fruit using RSM and their characterization. Molecules, 19: 9019-9032.

10. Liang, H., Wang, W., Xu, J., Zhang, Q., Shen, Z., Zeng, Z. \& $\mathrm{Li}$, Q. 2017. Optimization of ionic liquid-based microwave-assisted extraction technique for curcuminoids from Curcuma longa L. Food and Bioproducts Processing, 104: 57-65. the CHROMAC method. It can be concluded that the MRSM is accurate and reliable within a $95 \%$ confidence interval to predict the results obtained with $C$. longa.

\section{Conclusions}

The multi-response surface methodology was used successfully for the optimization conditions of UAE of antioxidant compounds from $C$. longa. The CCD provided a powerful design for the optimization conditions using UAE. The extraction factors strongly influenced the extraction of the antioxidant compounds from $C$. longa. We conclude that $C$. longa is a good and reliable source of antioxidant compounds.

11. Lima, C.F., Pereira-Wilson, C. \& Rattan, S.I. 2011. Curcumin induces hemeoxygenase-1 in normal human skin fibroblasts through redox signaling: relevance for antiaging intervention. Molecular Nutrition \& Food Research, 55: $430-442$.

12. Mandal, V., Mohan, Y. \& S. Hemalatha. 2008. Microwave assisted extraction of curcumin by sample-solvent dual heating mechanis musing Taguchi L9 orthogonal design. Journal of Pharmaceutical and Biomedical Analysis, 46: 322-327.

13. Mandal, V., Dewanjee, S., Sahu, R. \& Mandal, S.C. 2009. Design and optimization of ultrasound assistedex traction of curcumin as an effective alternative for conventional solid liquid extraction of natural products. Natural Product Communications, 4: 95-100.

14. Martínez-Morúa, A., Soto-Urquieta, M.G., Franco-Robles, E., Zúñiga-Trujillo, I., Campos-Cervantes, A., PérezVázquez, V. \& Ramírez-Emiliano, J. 2013. Curcumin decreases oxidative stress in mitochondria isolated from liver and kidneys of high-fatdiet-induced obesemice. Journal of Asian Natural Products Research, 15: 905-915.

15. Matshediso, P.G., Cukrowska, E. \& Chimuka, L. 2015. Development of pressurized hot water extraction (PHWE) for essential compounds from Moringa oleifera leaf extracts. Food Chemistry, 172: 423:427.

16. Mourtas, S., Lazar, A.N., Markoutsa, E., Duyckaerts, C. \& Antimisiaris, S.G. 2014. Multifunctional nanoliposomes with curcumin-lipid derivative and brain targeting functionality with potential applications for Alzheimer disease. European Journal of Medicinal Chemistry, 80: 175-183.

17. Nasır, N., Şahin, S., Çakmak, Z. E. \& Çakmak, T. 2017. Optimization of ultrasonic-assisted extraction via multiresponse surface for high antioxidant recovery from Chlorella sp. (Chlorophyta). Phycologia, 56(5): 561-569.

18. Péret-Almeida, L., Cherubino, A.P.F., Alves, R.J., Dufosse, L. \& Glória, M.B.A. 2005. Separation and determination of the physico-chemical characteristics of curcumin, emethoxy curcumin and bisdemethoxy curcumin. Food Research International, 38: 1039-1044.

19. Re, R., Pellegrini, N., Proteggente, A., Pannala, A., Yang, M. \& Rice-Evans, C. 1999. Antioxidant activity applying an improved ABTS radicalcation decolorization assay. Free Radical Biology and Medicine, 26: 1231-1237. 
20. Riela, S., Massaro, M., Colletti, C.G., Bommarito, A., Giordano, C., Milioto, S., Noto, R., Poma, P. \& Lazzara, G. 2014. Development and characterization of co-loaded curcumin/triazole-halloy site systems and evaluation of their potential anticancer activity. International Immunopharmacology, 475: 613-623.

21. Singleton, V.L., Orthofer, R. \& Lamuela-Raventos, R.M. 1999. Analysis of total phenols and other oxidation substrates and antioxidants by means of Folin-Ciocalteu reagent. Methods in Enzymology, 299: 152-178.

22. Şahin, S., Aybastıer, Ö. \& Işık, E., 2013. Optimisation of ultrasonic-assisted extraction of antioxidant compounds from Artemisia absinthium using response surface methodology. Food Chemistry, 141: 1361-1368.

23. Thoo, Y.Y., Ho, S.K., Liang, J.Y., Ho, C.W. \& Tan, C.P., 2010. Effects of binary solvent extraction system, extraction time and extraction temperature on phenolic antioxidants and antioxidant capacity from mengkudu (Morinda citrifolia). Food Chemistry, 120: 290-295.
24. Xu, H.Y. \& Bao, Y.H. 2014. Response surface optimization of extraction and antioxidant activity of total flavonoids from seed shell of Juglans mandshurica. Food of Science Technology Research, 20: 715-724.

25. Xu, J., Wang, W., Liang, H., Zhang, Q. \& Li, Q. 2015. Optimization of ionic liquid based ultrasonic assisted extraction of antioxidant compounds from Curcuma longa L. using response surface methodology. Industrial Crops and Products, 76: 487-493.

26. Xu, G., Hao, C., Tian, S., Gao, F., Sun, W. \& Sun, R. 2017. A method for the preparation of curcumin by ultrasonicassisted ammonium sulfate/ethanol aqueous two phase extraction. Journal of Chromatography B, 1041-1042: 167174.

27. Yap, C.F., Ho, C.W., Wan Aida, W.M. \& Chan, S.W. 2009. Optimization of extraction conditions of total phenolic compounds from star fruit (Averrhoa carambola L.) residues. Sains Malaysiana, 38(4): 511-520. 